\title{
COMPARISON OF TRUWINIST INTERDIGITAL METHOD AND CONVENTIONAL IN LEARNING APPROPRIATE DRUG SELECTION AND PRESCRIBING FOR TYPE 2 DIABETES MELLITUS
}

Trully Deti Rose Sitorus, Kuswinarti, Istriati

Departement of Pharmacology \&Therapy, Medical Faculty Universitas Padjadjaran, Bandung - INDONESIA

\begin{abstract}
Background: Medical education in Indonesia has been using Problem Based Learning curriculum. Meanwhile, the patient management ability evaluation showed the lowest result among all evaluation in Ujian Kompentensi Mahasiswa Program Pendidikan Dokter (UKMPPD). Truwinis Interdigital Method (TIM) has been developed to improve student ability in choosing the appropriate drug and prescribing for Diabetes Mellitus type 2. The purpose of this research is to compare the effectiveness of TIM toward Conventional Method (CM).

Methods: This research used cross-sectional design. The subject is 82 student who attend Clinical Skill Laboratory of Endocrine and Metabolism System of Faculty Medicine of Universitas Padjadjaran. The subject is divided into two groups, Group I: CM (control), Group II: TIM (Intervention). TIM consist of e-learning and audiovisual material. Parameters in this research were ability of choosing appropriate drugs test and Objective Skill Clinical Examination (OSCE). The data is analyzed statistically.

Results: The data showed homogenousity in both groups ( $p>0,05)$. The average test score for CM group was $25,11 \pm$ 10,84 and for TIM group was 80,06 $\pm 14,19$. This was statistically significant $(p<0,0001)$. The average test score of OSCE for CM group was 39,63 $\pm 11,73$ and for TIM group was $62,74 \pm 14,07$. This was also statistically significant $(p<0,0001)$.

Conclusion: Truwinist Interdigital Method is more effective than the Conventional Method in learning appropriate drugs selection and prescribing for type 2 Diabetes Mellitus.
\end{abstract}

Keywords: conventional, truwinist interdigital, test, OSCE.

\section{PERBANDINGAN METODE TRUWINIST INTERDIGITAL DENGAN KONVENSIONAL DALAM PEMILIHAN OBAT DAN PENULISAN RESEP OBAT DIABETES MELITUS TIPE 2}

\section{ABSTRAK}

Latar belakang: Pendidikan Fakultas Kedokteran di Indonesia umumnya telah menerapkan kurikulum berbasis kompetensi, namun hasil Ujian Kompetensi Mahasiswa Program Pendidikan Dokter (UKMPPD) menunjukkan rubrik manajemen pasien nilainya paling rendah dibandingkan rubik lainnya. Telah dikembangkan suatu Inovasi Pembelajaran Farmakologi dengan Metode Truwinist Interdigital (MTI) untuk meningkatkan kemampuan mahasiswa dalam memilih obat dan menulis resep obat Diabetes Mellitus tipe II. Tujuan penelitian ini adalah membandingkan efektivitas MTI terhadap metode konvensional.

Metode: Desain penelitian menggunakan model potong lintang, jumlah subjek 82 mahasiswa yang sedang mengikuti Clinical Skill Laboratory di sistem Endokrin dan Metabolisme Fakultas Kedokteran Universitas Padjadjaran. Subjek dibagi 2 kelompok, kelompok I yaitu Metode konvensional (kontrol) dan kelompok II adalah MTI (perlakuan). MTI terdiri dari e-learning dan audiovisual. Parameter penilaian adalah nilai tes untuk pemilihan obat dan nilai Objective Skill Clinical Examination (OSCE) untuk pemilihan obat dan

Contact: truly.sitorus@gmail.com 
keterampilan menulis resep. Data dianalisa secara statistik.

Hasil Penelitian: Hasil penelitian menunjukkan kedua kelompok homogen ( $p>0,05)$. Nilai rata-rata tes pemilihan obat kelompok konvensional 25,11 \pm 10,84 sedangkan kelompok MTI 80,06 $\pm 14,19$, secara statistik bermakna ( $\mathrm{p}<0,0001)$. Nilai rata-rata OSCE kelompok konvensional 39,63 $\pm 11,73$ dan kelompok MTI 62,74 $\pm 14,07$. juga bermakna $(\mathrm{p}<0,0001)$.

Kesimpulan: Metode Truwinist Interdigital lebih efektif dibandingkan metode konvensional dalam pembelajaran pemilihan obat dan penulisan resep untuk Diabetes Mellitus tipe 2.

Kata kunci: konvensional, truwinist interdigital, tes, OSCE.

\section{PENDAHULUAN}

Proses pendidikan di Fakultas Kedokteran bertujuan untuk mencapai kompetensi yang telah ditetapkan oleh Kementerian Riset Teknologi dan Perguruan Tinggi. Pendidikan di Fakultas Kedokteran ini sangat penting untuk meningkatkan derajat kesehatan bangsa Indonesia. ${ }^{1}$ Dalam melaksanakan kegiatan pendidikan beberapa Fakultas Kedokteran telah menerapkan kurikulum berbasis kompetensi yang berpusat pada mahasiswa (Student Centered Learning). ${ }^{2}$ Salah satu kompetensi yang harus dicapai oleh lulusan Fakultas Kedokteran yaitu mampu menetapkan diagnosis penyakit dan melakukan intervensi baik non farmakologi maupun farmakologi. ${ }^{3}$ Penanganan farmakologi menuntut kemampuan dalam memilih obat dan menuliskannya dalam selembar resep.

Kongres Ikatan Ahli Farmakologi Indonesia (IKAFI) di Jakarta tahun 2016 yang dihadiri oleh para farmakolog yang berkecimpung dalam pendidikan Farmakologi Fakultas Kedokteran di seluruh Indonesia, menyatakan bahwa pada umumnya lulusan Fakultas Kedokteran kurang mampu dalam memilih obat yang tepat dan kurang trampil menuliskannya dalam resep. Studi pelacakan (Tracer study) yang dilakukan Medical Education Research Development Unit terhadap alumni Fakultas Kedokteran Universitas Padjadjaran menyatakan bahwa penguasaan pemilihan obat dan ketrampilan dalam menulis resep kurang. Hal ini didukung dengan hasil pembicaraan komunikasi personal dengan panitia Ujian Kompetensi Program Profesi Dokter (UKMPPD), bahwa hasil ujian ketrampilan klinis yang disebut dengan Objective Structured Clinical Examination (OSCE), rubrik pengelolaan pasien yang meliputi antara lain pemilihan obat dan penulisan resep didapat nilai yang terendah dibandingkan rubrik lain nya.

Diabetes Melitus tipe 2 merupakan penyakit degeneratif yang prevalensinya semakin meningkat, penyakit ini tidak dapat disembuhkan, namun dapat dikendalikan sehingga mencegah mortalitas dan morbiditas akibat komplikasi yang ditimbulkannya4 Dalam Sistim Kompetensi Pendidikan Dokter Indonesia (SKDI), DM tipe 2 merupakan (kompetensi) tingkat 4A yaitu seorang dokter harus mampu mendiagnosis penyakit ini dan melakukan penatalaksanaan secara mandiri dan tuntas. ${ }^{3}$ Penatalaksanaan ini meliputi penanganan non farmakologis dan farmakologis. Prinsip penanganan Farmakologis adalah memilih obat yang tepat sesuai kondisi pasien dan menuliskan resepnya. ${ }^{5}$

Kegiatan Clinical Skill Laboratory (CSL) di Fakultas Kedokteran umumnya dilaksanakan dengan pemberian manual sebagai pedoman pembelajaran dan materi yang harus disiapkan oleh mahasiswa sebelum kegiatan tsb. Metode ini sering dianggap kurang menarik, kurang memberikan motivasi pada proses belajar farmakologi sehingga pengetahuan dasar farmakologi tidak tersampaikan dengan jelas dan benar, akibatnya mahasiswa tidak dapat mempersiapkan secara optimal, oleh karena itu pengetahuan dasar farmakologi kurang kuat akibatnya mahasiswa kurang mampu memilih obat pada berbagai kondisi pasien di fasilitas kesehatan. Berdasarkan hal-hal diatas harus dicari metode pembelajaran inovatif yang mendorong motivasi mahasiswa untuk belajar mandiri. Inovasi pembelajaran farmakologi ini diharapkan meningkatkan pemahaman mahasiswa sehingga mampu melaksanakan pemilihan obat yang tepat dan menulis resep dengan jelas dan benar. ${ }^{6}$ 
Metode Truwinist Intergital adalah suatu metode pembelajaran farmakologi yang inovatif yaitu kombinasi e-learning dan audiovisual. Pemaparan materi MTI disajikan secara bertahap dan sistimatik. Metode ini bertujuan untuk meningkatkan pemahaman mahasiswa dan mendorong motivasi mahasiswa untuk belajar mandiri (self directed learning) yang membentuk mahasiswa menjadi long life learner sesuai prinsip PBL.,8 Penggunaan metode e-learning ini juga dapat mengatasi kurangnya sumber daya manusia (SDM). SDM yang tidak mencukupi sebagai instruktur pada CSL atau laboratory activity merupakan salah satu masalah di beberapa fakultas kedokteran. Truwinist InterdigitaI ini belum pernah dilakukan pada pembelajaran Farmakologi.

Tujuan penelitian ini adalah:

1. Membandingkan metode truwinist interdigital dengan metode konvensional untuk meningkatkan pengetahuan mahasiswa dalam pemilihan obat.

2. Membandingkan metode truwinist interdigital dengan metode konvensional untuk meningkatkan ketrampilan mahasiswa dalam penulisan resep.

\section{METODE}

Desain penelitian ini adalah potong lintang. Penelitian ini dilaksanakan pada kegiatan CSL Sistim Endokrin dan Metabolisme, pada kegiatan semester ganjil tahun 2017. Tempat penelitian Gedung C.3.1 (Ruang CSL) Kampus Jatinangor Fakultas Kedokteran Universitas Padjadjaran.

Subjek penelitian adalah Mahasiswa Program Studi Pendidikan Dokter, semester 3, Fakultas kedokteran Universitas Padjadjaran, dengan kriteria inklusi bersedia mengikuti penelitian dengan cara mengisi dan menandatangani Inform consent, kriteria eksklusi adalah mahasiswa diluar kelompok yang ditentukan. Perhitungan jumlah subjek minimal adalah 73 orang. ${ }^{9}$ Subjek dibagi 2 kelompok yaitu kelompok I adalah kelompok konvensional yang menggunakan manual CSL farmakologi sebagai kontrol dan kelompok II adalah kelompok perlakuan yang menggunakan metode Truwinist Interdigital.

Persiapan pelaksanaan penelitian terdiri dari membuat rancangan MTI dan menuyusun materimateri obat DM tipe 2, yaitu e-learning Intervensi Pharmacology, Pharmacological Properties Isulin sekretagoga dan non sekretagoga, serta perbandingan obat dan prinsip pemilihan obat DM tipe 2. Sebelum digunakan dilakukan validasi MTI pada mahasiswa ilmu keperawatan UNPAD. Validasi dan pelaksanaan penelitian dilakukan di kampus jatinangor KM 21 Sumedang. Etik penelitian diajukan ke komisi etik fakultas kedokteran UNPAD. Persiapan lain berupa pembuatan soal pre-post test, kasus OSCE serta rubrik evaluasinya. Prosedur pelaksanaan penelitian dapat dilihat pada Gambar 1.

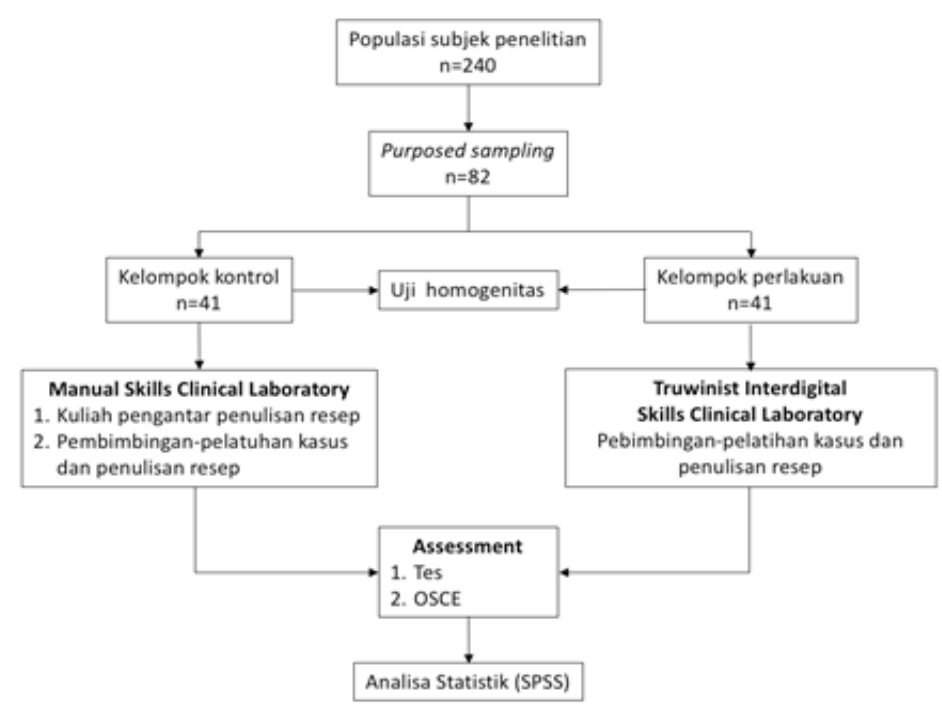

Gambar 1. Prosedur Penelitian 


\section{HASIL DAN PEMBAHASAN}

Subjek penelitian yang memenuhi kriteria inklusi dan eksklusi berjumlah 82 orang, yang terdiri dari 2 kelompok. Uji homogenitas ( $p>0,05)$ menunjukkan kedua kelompok homogen. Sebaran data hasil tes pemilihan obat DM tipe 2 dan OSCE kedua kelompok tidak normal, sehingga digunakan analisis non parametrik. ${ }^{9}$

Nilai tes pemahaman mahasiswa akan farmakologi obat DM tipe 2 untuk kelompok truwinist interdigital lebih tinggi dengan nilai rata-rata $80,06 \pm 14,19$ dibandingkan kelompok konvensional dengan ratarata $25,11 \pm 10,83$. Perbedaan ini sangat signifikan secara statistik ( $<<0,0001)$. Berdasarkan uji MannWhitney didapatkan hasil bahwa terdapat perbedaan median nilai tes antara mahasiswa yang mendapatkan metode Truwinist interdigital dan konvensional ( $p<0,0001$ ). Median (min-maks) nilai tes mahasiswa yang mendapatkan metode Truwinist interdigital adalah 82 (31-100) sementara yang mendapatkan metode konvensional adalah 23 (4-52). Data hasil tes pemilihan obat pada kedua metode dapat dilihat pada Tabel 1 .

Tabel 1. Hasil tes pemilihan obat pada kelompok konvensional dan truwinist-interdigital

\begin{tabular}{cccc}
\multirow{2}{*}{ Nilai } & \multicolumn{2}{c}{ Metode } & \\
\cline { 2 - 3 } & Konvensional & $\begin{array}{c}\text { Truwinist } \\
\text { Interdigital }\end{array}$ & \\
Rata-value & \\
Terendah & $25,11 \pm 10,83$ & $80,06 \pm 14,19$ & \\
Tertinggi & 4 & 31 & $<0,0001$ \\
\hline
\end{tabular}

Penelitian ini menunjukkan bahwa nilai rata-rata OSCE kelompok Truwinist Interdigital juga lebih tinggi dibandingkan dengan nilai rata-rata kelompok konvensional yaitu $62,74 \pm 14,07$ vs $39,63 \pm 1,73$, yang berbeda bermakna secara statistik $(p<0,0001)$. Berdasarkan uji Mann-Whitney didapatkan hasil bahwa terdapat perbedaan median nilai OSCE antara mahasiswa yang mendapatkan metode Truwinist Interdigital dan konvensional $(\mathrm{p}<0,0001)$. Median (min-maks) nilai OSCE mahasiswa yang mendapatkan metode Truwinist adalah 67 (39-91) dan yang mendapatkan metode konvensional adalah
35 (21-67). Dengan batas minimal kelulusan adalah 80 , terdapata 23 orang mahasiswa yang lulus pada metode truwinist interdigital, sedangkan mahasiswa dengan metode konvensional tidak ada yang lulus. Data hasil OSCE pada kedua metode dapat dilihat pada Tabel 2.

Tabel 2. Hasil OSCE kelompok konvensional dengan truwinist interdigital

\begin{tabular}{cccl}
\multirow{2}{*}{ Nilai } & \multicolumn{2}{c}{ Metode } & \\
\cline { 2 - 3 } & Konvensional & $\begin{array}{c}\text { Truwinist } \\
\text { Interdigital }\end{array}$ & p-value \\
Rata-rata & $39,63 \pm 11,73$ & $62,74 \pm 14,07$ & \\
Terendah & 21 & 39 & $<0,0001$ \\
Tertinggi & 67 & 91 & \\
\hline
\end{tabular}

Inovasi pembelajaran merupakan hal mendasar dan penting sebagai solusi dari berbagai tuntutan kebutuhan atau masalah yang terjadi di lingkungan institusi pendidikan. termasuk di Fakultas Kedokteran. Masalah di Fakultas Kedokteran saat ini adalah lulusan kurang mampu memilh obat dan menulis resep. Fakultas Kedokteran di Indonesia umumnya menggunakan kurikulum yang bersifat studentcentred learning. Salah satu prinsip pembelajaran student-centred learning adalah penyediaan sumber atau panduan belajar. ${ }^{10}$ Truwinist Interdigital dirancang sebagai wujud pembelajaran farmakologi yang inovatif untuk meningkatkan kemampuan mahasiswa dalam memilih obat yang sesuai dengan kondisi pasien dan menuliskan nya dalam resep. Metode Truwinist interdigital ini bersifat baru yang berbeda dengan metode yang sedang berjalan pada kegiatan SCL saat ini. dijalankan saat ini. Hal ini sesuai dengan karakter inovasi pembelajaran dan prinsip self-directed learning. ${ }^{2,6}$

Materi Farmakologi truwinist interdigital, dipaparkan secara bertahap dan sistimatik. Pada tahap awal dipaparkan tentang patofisiologi DM, obatobat yang digunakan pada pengobatan DM sehingga mahasiswa mampu mengkaitkan kedua hal tersebut dan menuangkannya dalam intervensi Farmakologi DM. Selanjutnya dipaparkan tentang pharmacological properties obat-obat DM tipe 
2, pengetahuan ini merupakan dasar kuat dalam pemilihan obat yang tepat pada setiap kasus. Pembahasan Pharmacological properties obat di lengkapi dengan pembuatan "TruliS Pharmacology Concept Mapping." Tujuannya adalah menfasilitasi mahasiswa untuk berfikir dan menghubungkan sifat farmakologi satu dengan lain, sehingga akan memperkuat pemahaman, meningkatkan retensi memory dan mengembangkan metacognitive thinking. ${ }^{11}$ Paparan selanjut nya adalah perbandingan obat-obat DM disertai kasus-kasus yang memberi kesempatan bagi mahasiswa untuk mengaplikasikan ilmunya dalam menangani kasus DM. Diharapkan mahasiswa mampu mengidentifikasi masalah pasien meliputi kondisi pasien menetapkan tujuan terapi dan memilih obat yang tepat sesuai dengan kondisi pasien. ${ }^{12}$ Pemahaman ini mempersiapkan mahasiswa menghadapi pasien DM tipe 2 dengan berbagai kondisi di fasilitas kesehatan sebagai dokter. Berbagai kondisi pasien yang di jumpai di fasilitas kesehatan antara lain DM tipe 2 dengan atau tanpa komplikasi, DM yang disertai gangguan ginjal, gangguan hati, osteoporosis, gangguan paru, jantung maupun DM pada kehamilan, laktasi atau geriatrik atau adanya interaksi obat. ${ }^{13,14}$

Hasil penelitian pada tabel 1 menunjukkan hasil-hasil test pemilihan obat DM tipe 2 kelompok mahasiswa yang menggunakan Truwinist Interdigital lebih baik dengan nilai rata-rata $80,06 \pm 14,19$ dibandingkan kelompok kotrol dengan nilai rata-rata $25,11 \pm 10,84$, yang secara statistik sangat bermakna $(p<0,0001)$. Parameter ini bertujuan untuk menunjukan kemampuan berfikir yang meliputi kemampuan mengingat, memahami, menghubungkan dan menggabungkan pemahaman farmakologi sehingga dapat memecahkan masalah. Hal ini menunjukkan truwinist interdigital berkonstribusi dalam mengembangkan kemampuan metacognitive thinking. ${ }^{11}$

Aspek psikomotor dalam metode truwinist interdigital adalah berkaitan dengan ketrampilan (skill) yaitu kemampuan dalam penulisan resep disajikan dengan media audiovisual yaitu video. Video ini memaparkan 2 orang mahasiswa yang interaktif, saling bertanya dalam mempelajari caracara penulisan resep yang benar dan jelas. Video ini memaparkan cara penulisan resep yang benar sesuai dengan kaidah dan undang-undang, yaitu penulisan resep harus lengkap, jelas dan benar. ${ }^{15}$ Ketidaklengkapan, ketidakjelasan atau tulisan yang tidak terbaca dalam resep dapat menyebabkan medication error yang tidak hanya merugikan namun dapat membahayakan pasien. ${ }^{16}$ Beberapa penelitian di Indonesia menunjukkan sejumlah medication error 99,12\% adalah prescribing error atau kesalahan akibat penulisan resep. Salah satu penyebab medical error adalah kurang nya pengetahuan dokter dalam menetapkan dosis obat, salah menulis dosis obat dan tulisan yang tidak jelas. ${ }^{16}$ Materi video ini juga dilengkapi dengan kesalahan-kesalahan dalam penulisan resep yang sering ditemukan di lapangan, pengalaman pembelajaran ini (experience of learning) akan membentuk sikap mahasiswa untuk tidak berperilaku yang sama. Hal ini menunjukkan aspek afektif yang melekat pada sikap mahasiswa saat berperan sebagai praktisi. ${ }^{18}$ Perilaku ini diharapkan akan menghindari penulisan resep yang irrasional sehingga dapat mengurangi kejadian yang tidak diinginkan seperti efek samping obat, kegagalan terapi atau penyakit yang tidak tersembuhkan, peningkatan biaya pengobatan. dan mungkin juga sampai ke masalah hukum.

Evaluasi untuk kemampuan psikomotor ini ditunjukkan dengan uji ketrampilan penulisan resep pada Objective-Structured Clinical Examination. Kesalahan peresepan meliputi pengambilan keputusan dalam pemilihan obat yang tidak tepat untuk pasien yang mempertimbangkan adanya alergi, interaksi obat, kondisi patologis seperti gangguan organ, kondisi fisiologis seperti kehamilan dan penetapan regimen pemberian yang meliputi dosis, bentuk sediaan, interval, cara dan saat pemberian obat, maka pada OSCE ini mencakup uji pemilihan obat, regimen dosis dan penulisan resep. Hasil penelitian yang ditunjukkan pada tabel 2 , nilai ratarata OSCE truwinist interdigital lebih tinggi (ratarata $62,74 \pm 14,06$ ), dibandingkan kelompok kontrol (rata-rata $39,63 \pm 11,73$ ) yang secara statistik sangat bermakna $(p<0,0001)$. Hasil ini membuktikan bahwa metode truwinist interdigital dapat meningkatkan psikomotor mahasiswa dalam memilih dan menulis resep yang baik dan benar. Ketrampilan psikomotor 
ini merupakan kelanjutan dari hasil belajar kognitif yaitu memahami materi pemilihan obat.

Metode inovatif dengan menggunakan e-learning dan video ini, juga berdampak pada pengurangan jumlah instruktur yang diperlukan dalam kegiatan SCL atau Laboratory Activity yang sering menjadi permasalahan pada sistim pembelajaran yang membutuhkan sumber daya manusia (SDM). Pada pembelajaran SCL secara konvensional di butuhkan SDM sebagai instruktur yang rata-rata adalah 4-5 orang sesuai dengan jumlah kelompok pada kegiatan tersebut secara efektif. Pada metode truwinist interdigital jumlah instruktur yang diperlukan lebih sedikit.

\section{KETERBATASAN PENELITIAN}

Dalam penelitian ini pemaparan e-learning maupun video dilaksanakan di kampus dengan waktu terbatas (terlalu singkat) tidak sesuai dengan beban materi.

\section{KESIMPULAN}

Berdasarkan hasil analisis data dan pembahasan yang telah diuraikan diperoleh kesimpulan sebagai berikut, metode truwinist interdigital lebih efektif dalam meningkatkan pengetahuan farmakologi pada pemilihan obat dan keterampilan penulisan resep obat Diabetes Melitus tipe 2.

\section{UCAPAN TERIMAKASIH}

Peneliti mengucapkan terimakasih kepada Prof. Dr. Med Tri Hanggono Achmad, dr. selaku Rektor Universitas Padjadjaran. Alamat: Gedung Rektorat Unpad. Jln. Raya Bandung Jatinangor Sumedang 45363, atas dukungan pada penelitian ini melalui Hibah internal Universitas.

\section{DAFTAR PUSTAKA}

1. Buku Panduan Pengembangan kurikulum berbasis Kompetensi Pendidikan Tinggi. Jakarta: Direktorat Akademik Jendral Pendidikan Tinggi; 2008.

2. Mety N, Prihatiningsih TS, Suryadi E. Penerapan selfdirected learning melaui sistim PBL pada mahasiswa kedokteran di Asia. Jurnal Pendidikan Kedokteran Indonesia, 2017;6(3)

3. Konsil Kedokteran Indonesia. Standar Kompetensi Dokter Indonesia. edisi 2. Jakarta: KKI; 2012.
4. Nwari C, Cooper H, Jones DB. Mortality in type 2 daibetes mellitus: Magnitude of evidence from a systematic review and meta-analysis. The British Journal, 2013;3(4).

5. Brunton L, Chabner B, Knollman B. Endocrine Pancreas and Pharmacotherapy of Diabetes Mellitus \& Hipoglicemic. in Goodman \& Gilman's The Pharmacological Basis of Therapeutic 13th Ed; 2018.

6. Suhoyo Y. Konsep Inovasi Strategi Pendidikan di Institusi Pendidikan Kedokteran. Jurnal Pendidikan Kedokteran Indonesia, 2012;1(2).

7. Khan KA, Asima B, Rajkumar J. Problem based learning in medical education: A review. Journal Education in Research \& Medical Teacher, 2014;2(2):1-5.

8. Imanien $\mathrm{MH}$, Dehghani $\mathrm{SH}$, Sobhani AR, Maghighat M. Evaluation of Problem learning in medical student's education. J Adv Med. Educ.Prof.2014 2(1):1-5.

9. Dahlan MS. Statistika untuk kedokteran: deskriptif, bivariat, dan multivariate. ed. 6. Jakarta; 2016.

10. Dent JA, Harden RM, editors. A practical guide for medical teachers, 2nd ed. London: Elsever Churchill Livingstone; 2005.

11. Srini MI. Pendekatan Ketrampilan Metacognitif dalam pembelajaran sains di kelas. Erudio 2016;2(2).

12. Simatupang A. Pedoman tentang Penulisan Resep yang baik sebagai bagian Penggunaan obat yang rasional. Majalah Kedokteran FK UKI, 2012;23(1).

13. Chaundhury A, Duvoor C, Dendi WSR, Kraleti S, Ravilla R, et al. Clinical Review of Antidiabetic Drugs: Implications for type 2 Diabetes Mellitus Management. Journal Front. Endocinol, 2017;8(6).

14. Moon MK, Hur KY, Hyonko S, Wanlee B. Kim H, et al. Combination therapy of oral hypoglycemic agents in patient with type 2 diabetes mellitus. Korean J Intern Med, 2017;32(6).

15. Amalia DT, Sukohar A. Rational Prescription Writing. JUKE, 2014;4(7).

16. Ulfah SS, Mita SR. Medication errors pada tahap prescribing, transcribing, dispensing dan Admnistering. Farmaka, 2017;15Suppl(2).

17. Tajuddin RS, Sudirman I, Maidin A. Faktor penyebab medication error di Instalasi rawat darurat. Jurnal Manajemen Pelayanan Kesehatan, 2012;15(4).

18. Surmiyati, Kristayulita, Sripatmi. Analisis Kemampuan Kognitif dan kemampuan Psikomotor setelah penerapan KTSP. Jurnal Beta, 2014Mei;7(1). 